\title{
Microwave-assisted $\mathrm{Cu}(\mathrm{l})$-catalyzed, three- component synthesis of 2-(4-((1-phenyl-1H-1,2,3- triazol-4-yl)methoxy)phenyl)-1H-benzo[d]imidazoles
}

\author{
Yogesh Kumar ${ }^{1}$, Vijay Bahadur ${ }^{1}$, Anil K. Singh ${ }^{1}$, Virinder S. Parmar ${ }^{1}$, \\ Erik V. Van der Eycken ${ }^{2}$ and Brajendra K. Singh ${ }^{* 1}$
}

\section{Full Research Paper}

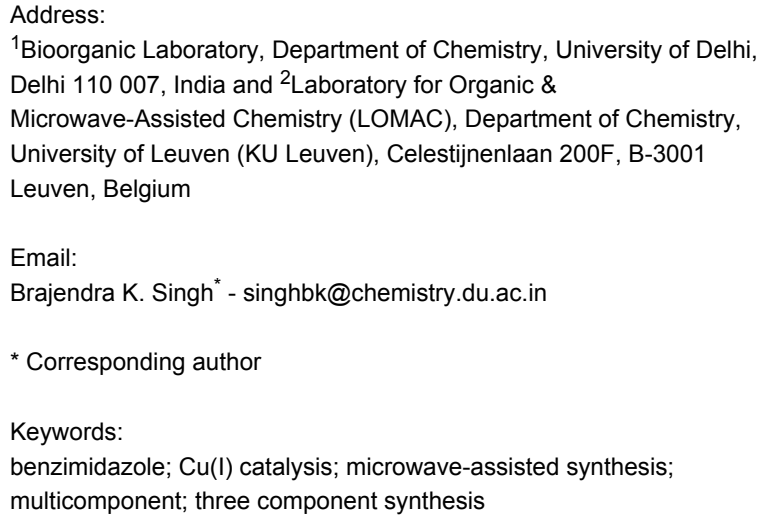

${ }^{1}$ Bioorganic Laboratory, Department of Chemistry, University of Delhi, Delhi 110 007, India and ${ }^{2}$ Laboratory for Organic \& Microwave-Assisted Chemistry (LOMAC), Department of Chemistry, University of Leuven (KU Leuven), Celestijnenlaan 200F, B-3001 Leuven, Belgium

Email:

Brajendra K. Singh ${ }^{*}$ - singhbk@chemistry.du.ac.in

* Corresponding author

Keywords:

benzimidazole; $\mathrm{Cu}(\mathrm{I})$ catalysis; microwave-assisted synthesis; multicomponent; three component synthesis

\author{
Beilstein J. Org. Chem. 2014, 10, 1413-1420. \\ doi:10.3762/bjoc. 10.145 \\ Received: 16 February 2014 \\ Accepted: 22 May 2014 \\ Published: 24 June 2014 \\ Guest Editor: T. J. J. Müller \\ (c) 2014 Kumar et al; licensee Beilstein-Institut. \\ License and terms: see end of document.
}

This article is part of the Thematic Series "Multicomponent reactions II".

\begin{abstract}
A microwave-assisted synthesis of 2-(4-((1-phenyl-1H-1,2,3-triazol-4-yl)methoxy)phenyl)-1H-benzo[ $d]$ imidazoles from a phenylazide, propargyloxybenzaldehyde and a 1,2-diaminobenzene is proposed.
\end{abstract}

\section{Introduction}

Due to their structural range and biological importance nitrogen-containing heterocycles have been striking targets for many years. They are found in a variety of natural products and are characterized by an appreciable chemical and biological importance. The synthesis of nitrogen-containing heterocyclic compounds and their derivatives plays an important role in organic chemistry as they frequently exhibit therapeutic and pharmacological properties. They have emerged as an integral backbone of several existing drugs. Various medicinal agents are composed of several heterocyclic rings in which the benzimidazole and the 1,2,3-triazole constitute an important position. Benzimidazole derivatives have been shown to posses anticancer [1,2], antihypertensive [3], antibacterial [4] and enzyme inhibition activity $[5,6]$. They have also been used to synthesize dyes [7], chemosensitizers [8] and fluorophores [9]. Triazole derivatives have shown antifungal [10], anticancer [11] antituberculosis [12] and antimicrobial [13] activities. Recently, hybrid molecules, connecting two or more distinct drug entities 
in one molecule, have drawn the attention of medicinal chemists [14-18]. This logical approach is a promising path for those drug molecules which can effectively and selectively target multifunctional diseases. It has also been found that hybrid molecules are sometimes much more effective than the sum of their individual components.

The therapeutic application of 2-(3-fluoro-phenyl)-1-[1-(substituted-phenyl)- $1 H$-[1,2,3]-triazol-4-yl-methyl)- $1 H$ benzo $[d]$ imidazoles has been demonstrated by treating tuberculosis[19]. However, there has been little progress in the development of such hybrid molecules to date. An extensive literature survey revealed the existence of a multistep synthesis with low yields and long reaction times. This encouraged us to develop a new methodology for this synthesis.

\section{Results and Discussion}

Three different approaches for the construction of the proposed 2-(4-((1-phenyl-1H-1,2,3-triazol-4-yl)methoxy)phenyl)- $1 H$ benzo $[d]$ imidazole are illustrated in Scheme 1. In a two-step process the triazole and imidazole ring are synthesized consecu- tively (Scheme 1, path A and B). However, we reasoned that the desired adduct could also be formed in a one-pot fashion (Scheme 1, path C) as a multicomponent reaction (MCR). The utility and importance of MCRs have been recognized by chemists [20-23]. Several MCRs are now well-established reactions, such as Ugi [24], Passerini [25], Van Leusen [26], Strecker [27], Hantzsch [28], and Biginelli [29-31].

However, when path A and path B were explored, the desired product was afforded in different yields (Scheme 1). The treatment of acetylene $\mathbf{2 a}$ with phenylazide (1a) in the presence of copper sulfate and D-glucose as a reductant [32,33] in THF/ $\mathrm{H}_{2} \mathrm{O}(2: 1)$ as a solvent under stirring at $\mathrm{rt}$ as well as under microwave irradiation resulted in the obtainment of the desired product in excellent yields of $91 \%$ and $95 \%$ in $12 \mathrm{~h}$ and $15 \mathrm{~min}$, respectively. However, when the manufactured 4-((1-phenyl1H-1,2,3-triazol-4-yl)methoxy)benzaldehyde was treated with 1,2-diaminobenzene, the desired product was obtained in an inferior yield of $59 \%$ and $42 \%$ under conventional heating and microwave irradiation in 50 and $20 \mathrm{~min}$, respectively (path A). On the other hand, when 4-(prop-2-yn-1-yloxy)benzaldehyde
Path A<smiles>C#CCOc1ccc(C=O)cc1</smiles>

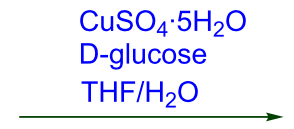

$\mathrm{MW}, 100 \mathrm{~W}$, $70{ }^{\circ} \mathrm{C}, 15 \mathrm{~min}$, yield $=95 \%$, or, rt, $12 \mathrm{~h}$, yield $=91 \%$

2a

Path C<smiles>Nc1ccccc1</smiles>

$1 \mathrm{a}$<smiles>C#CCOc1ccc(C=O)cc1</smiles>

2a<smiles>C#CCOC1=C[C+]=C(C=O)C=C1</smiles>

2a<smiles>Nc1ccccc1N</smiles>

$3 a$<smiles>Nc1ccccc1N</smiles>

$3 a$

$\mathrm{MW}, 100 \mathrm{~W}, 110^{\circ} \mathrm{C}$
$20 \mathrm{~min}$, yield $=42 \%$ or, reflux, $50 \mathrm{~min}$, yield $=59 \%$

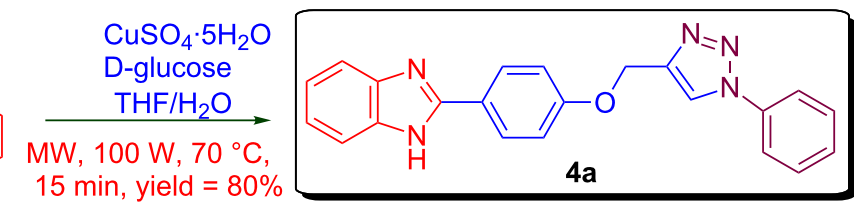

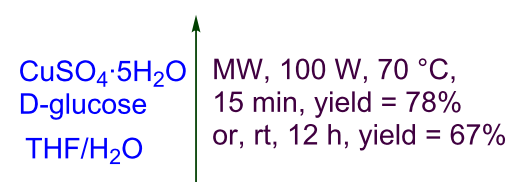

toluene $\mathrm{MW}, 100 \mathrm{~W}, 110^{\circ} \mathrm{C}$ $20 \mathrm{~min}$, yield $=54 \%$ or, reflux, $90 \mathrm{~min}$, yield $=70 \%$

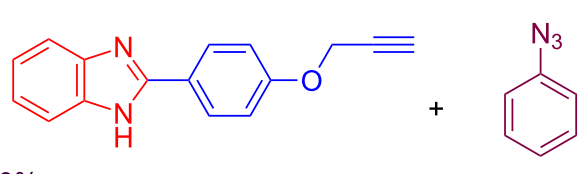

1a 
(2a) was first treated with 1,2-diaminobenzene in the presence of copper sulfate and D-glucose in a $\mathrm{THF} / \mathrm{H}_{2} \mathrm{O}(2: 1)$ mixture under conventional heating as well as microwave irradiation, the desired product was obtained in a better yield (70\%) under conventional heating compared to microwave irradiation (54\% yield). The compound was subsequently coupled with phenylazide (1a), which afforded the desired product in $67 \%$ and $78 \%$ yield upon stirring at $\mathrm{rt}$ and microwave irradiation, respectively (path B). However, in the MCR approach (Scheme 1, path C) the desired product was obtained in a good yield. The reaction proceeded smoothly in the presence of $\mathrm{CuSO}_{4} \cdot 5 \mathrm{H}_{2} \mathrm{O}$ and D-glucose under microwave irradiation for $15 \mathrm{~min}$ and gave the desired compound in $80 \%$ yield. Surprisingly, under conventional heating with this MCR approach no product formation was observed, even after an extended period of time ( $24 \mathrm{~h})$ with heating under reflux .

In order to optimize the reaction conditions for this protocol, we screened several organic solvents. We explored the reaction between phenylazide (1a), 4-(prop-2-yn-1-yloxy)benzaldehyde (2a) and 1,2-diaminobenzene (3a). It was found that when the reactions were carried out in polar solvents, such as acetonitrile,
$N, N$-dimethylformamide (DMF), dimethylsulfoxide (DMSO) or 1,4-dioxane, no product formation was observed (Table 1, entries 1-4). However, upon microwave irridiation the reaction went to completion in a non-polar solvent, such as tetrahydrofuran (THF) or toulene, and the desired product was isolated in $20 \%$ and $25 \%$ yields (Table 1 , entry 5 and entry 6 ) in THF and toluene, respectively. Moreover, when the reaction was carried out in an aqueous solvent system, decent improvements of the yields were observed (Table 1, entries 7-11). The best result was obtained with $\mathrm{THF} / \mathrm{H}_{2} \mathrm{O} 2: 1$ (Table 1, entry 8). It is believed that the higher solubility of $\mathrm{CuSO}_{4}$ in this aqueous solvent system is responsible for the enhanced product formation. On the contrary, the formation of aggregates of the copper acetylide intermediate in polar solvents results in a failure of the reaction [34].

Various 1,2-diaminobenzenes $\mathbf{3 a}, \mathbf{b}$ and phenylazides $\mathbf{1 a - j}$ were explored in order to estabilish the applicability of this protocol and the results are summarized in Table 2. Different azides 1a-j with electron-donating groups (Table 2, entries 2-8, 12-17, 20-23), electron-withdrawing groups (Table 2, entries 9, 10, 18 and 19), two different 4-(prop-2-yn-1-yloxy)benzaldehydes

Table 1: Optimization of the solvent system. ${ }^{a}$

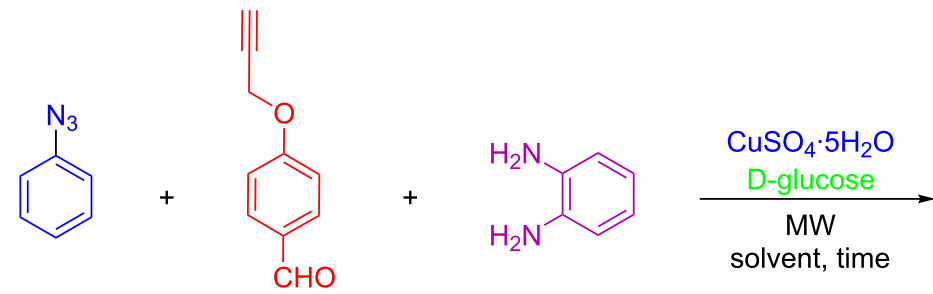

1 a

$2 \mathbf{a}$
$3 a$

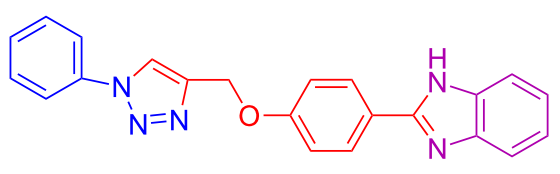

$4 a$

\begin{tabular}{|c|c|c|c|}
\hline Entry & Solvent & Time $(\min ) /$ temperature $\left({ }^{\circ} \mathrm{C}\right)$ & Yield $(\%)^{b}$ \\
\hline 1 & Acetonitrile & $30 / 80$ & 0 \\
\hline 2 & DMF & $15 / 100$ & 0 \\
\hline 3 & DMSO & $15 / 100$ & 0 \\
\hline 4 & 1,4-Dioxane & $15 / 110$ & 0 \\
\hline 5 & THF & $20 / 70$ & 20 \\
\hline 6 & Toluene & $20 / 100$ & 25 \\
\hline 7 & Toluene/ $\mathrm{H}_{2} \mathrm{O} 2: 1$ & $20 / 100$ & 56 \\
\hline 8 & $\mathrm{THF} / \mathrm{H}_{2} \mathrm{O} 2: 1$ & $15 / 70$ & 80 \\
\hline 9 & $\mathrm{DMF} / \mathrm{H}_{2} \mathrm{O} 2: 1$ & $15 / 100$ & 30 \\
\hline 10 & $\mathrm{DMSO} / \mathrm{H}_{2} \mathrm{O} 2: 1$ & $15 / 100$ & 25 \\
\hline 11 & 1,4-Dioxane $/ \mathrm{H}_{2} \mathrm{O} 2: 1$ & $15 / 100$ & 40 \\
\hline
\end{tabular}

aphenylazide (1a, $1.0 \mathrm{mmol}$ ), 4-(prop-2-yn-1-yloxy)benzaldehyde (2a, $1.2 \mathrm{mmol}), 1,2$-diaminobenzene $(\mathbf{3 a}, 2 \mathrm{mmol}), \mathrm{CuSO}_{4} \cdot 5 \mathrm{H}_{2} \mathrm{O}(0.2 \mathrm{equiv})$, $\mathrm{D}$-glucose $\left(0.4\right.$ equiv) in different solvents were irradiated for the indicated time and temperature at $100 \mathrm{~W}$ maximum power; ${ }^{\circ}$ isolated yields. 
Table 2: Scope and limitations of the protocol employing different 4-(prop-2-yn-1-yloxy)benzaldehydes (2), phenylazides (1) and 1,2-diaminobenzenes $(3)^{\mathrm{a}}$

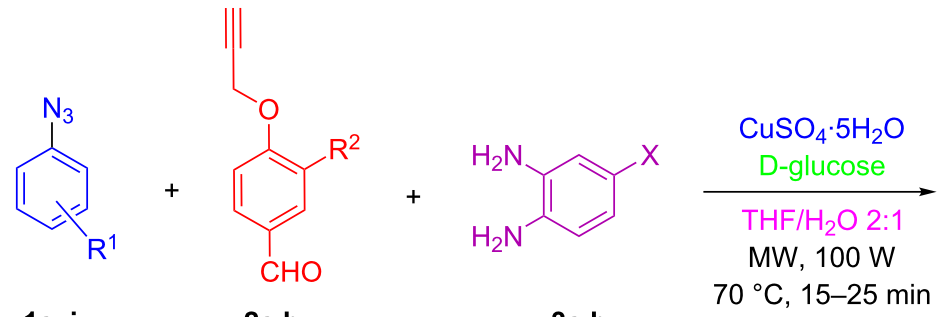

$1 \mathrm{a}-\mathrm{j}$

Entry

$2 a, b$

$\begin{array}{lll}\mathrm{R}^{1} & \mathrm{R}^{2} & \mathrm{X}\end{array}$

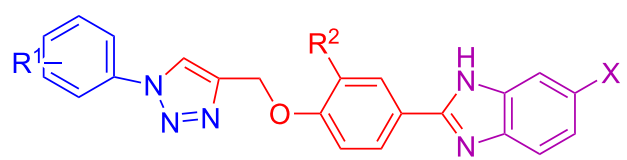

$4 a-w$

$\mathrm{H}$<smiles>c1ccc(-n2cc(COc3ccc(-c4nc5ccccc5[nH]4)cc3)nn2)cc1</smiles>

$4 a$<smiles>COc1ccc(-n2cc(COc3ccc(-c4nc5ccccc5[nH]4)cc3)nn2)cc1</smiles>

$4 b$

$2 \quad 4-\mathrm{OCH}_{3} \quad \mathrm{H} \quad \mathrm{H}$<smiles>COc1cccc(-n2cc(COc3ccc(-c4nc5ccccc5[nH]4)cc3)nn2)c1</smiles>

4c

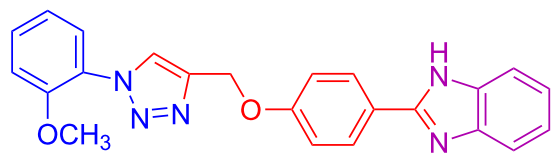

4d<smiles>Cc1ccc(-n2cc(COc3ccc(-c4nc5ccccc5[nH]4)cc3)nn2)cc1</smiles>

$4 e$<smiles>Cc1cccc(-n2cc(COc3ccc(-c4nc5ccccc5[nH]4)cc3)nn2)c1</smiles>

$68^{c}$

$4 f$

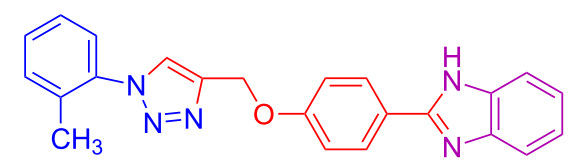

$4 \mathrm{~g}$<smiles>Brc1ccc(-n2cc(COc3ccc(-c4nc5ccccc5[nH]4)cc3)nn2)cc1</smiles>

75

$4 h$ 
Table 2: Scope and limitations of the protocol employing different 4-(prop-2-yn-1-yloxy)benzaldehydes (2), phenylazides (1) and 1,2-diaminobenzenes $(3)^{\mathrm{a}}$. (continued)

9

12 4- $\mathrm{OCH}_{3}$

$\mathrm{H}$

$\mathrm{H}$

$\mathrm{H}$

$\mathrm{H}$

$\mathrm{H}$

$\mathrm{H}$<smiles>Clc1cccc(-n2cc(COc3ccc(-c4nc5ccccc5[nH]4)cc3)nn2)c1</smiles>

$4 i$<smiles>Fc1ccccc1-n1cc(COc2ccc(-c3nc4ccccc4[nH]3)cc2)nn1</smiles>

4j

$\mathrm{Cl}$<smiles>Clc1ccc2nc(-c3ccc(OCc4cn(-c5ccccc5)nn4)cc3)[nH]c2c1</smiles>

Cl<smiles>COc1ccc(-n2cc(COc3ccc(-c4nc5ccc(Cl)cc5[nH]4)cc3)nn2)cc1</smiles>

4I<smiles>COc1cccc(-n2cc(COc3ccc(-c4nc5ccc(Cl)cc5[nH]4)cc3)nn2)c1</smiles>

$4 m$
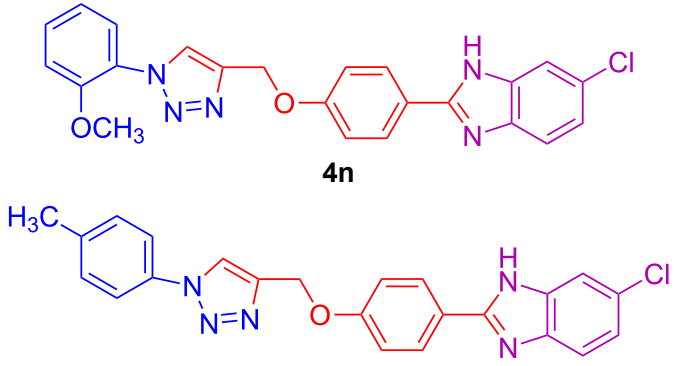

40<smiles>Cc1cccc(-n2cc(COc3ccc(-c4nc5ccc(Cl)cc5[nH]4)cc3)nn2)c1</smiles>

$4 p$<smiles>Clc1ccc2nc(-c3ccc(OCc4cn(-c5ccc(Br)cc5)nn4)cc3)[nH]c2c1</smiles>

$4 q$

Cl<smiles>Clc1cccc(-n2cc(COc3ccc(-c4nc5ccc(Cl)cc5[nH]4)cc3)nn2)c1</smiles>
$60^{c}$ 90 91 
Table 2: Scope and limitations of the protocol employing different 4-(prop-2-yn-1-yloxy)benzaldehydes (2), phenylazides (1) and 1,2-diaminobenzenes $(3)^{a}$. (continued)

19

2-F

$\mathrm{H}$

4- $\mathrm{CH}_{3}$

$\mathrm{OCH}_{3}$

$\mathrm{H}$

$\mathrm{Cl}$

20

21

$4-\mathrm{OCH}_{3}$

$\mathrm{OCH}_{3}$

22

4- $\mathrm{CH}_{3}$

$\mathrm{OCH}_{3}$

23

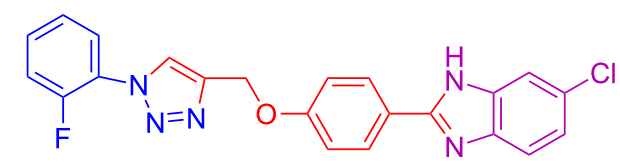

4s<smiles>COc1cc(-c2nc3ccccc3[nH]2)ccc1OCc1cn(-c2ccc(C)cc2)nn1</smiles>

$4 \mathbf{t}$<smiles>COc1ccc(-n2cc(COc3ccc(-c4nc5ccccc5[nH]4)cc3OC)nn2)cc1</smiles>

$4 \mathrm{u}$<smiles>COc1cc(-c2nc3ccc(C)cc3[nH]2)ccc1OCc1cn(-c2ccc(C)cc2)nn1</smiles>

$4 v$<smiles>COc1ccc(-n2cc(COc3ccc(-c4nc5ccc(Cl)cc5[nH]4)cc3OC)nn2)cc1</smiles>

$4 \mathbf{w}$ $67^{c}$

69

aPhenylazide 1 (1.0 mmol), propargyloxybenzaldehyde 2 (1.2 mmol), 1,2-diaminobenzene $3(2 \mathrm{mmol}), \mathrm{CuSO}_{4} \cdot 5 \mathrm{H}_{2} \mathrm{O}(0.2$ equiv), D-glucose ( 0.4 equiv) were irradiated at $70^{\circ} \mathrm{C}$ and $100 \mathrm{~W}$ maximum power; ${ }^{b}$ isolated yields after work-up, no further purification was required; ${ }^{\circ}$ Isolated yields after column chromatography.

$\mathbf{2 a}, \mathbf{b}$, and two different 1,2-diaminobenzenes $\mathbf{3 a}, \mathbf{b}$ were used. In general, good to excellent yields were obtained for the desired cyclized products.

\section{Plausible mechanism}

The desired product could be obtained by the two mechanistic pathways A and B as described in Scheme 2. The CuAAC could take place prior to or after benzimidazole formation and we do not have a clear mechanistic proof. However, we believe that if the reaction proceed via route $\mathrm{A}$ in situ generation of $\mathrm{Cu}(\mathrm{I})$ $[32,33]$ from $\mathrm{Cu}(\mathrm{II})$ takes place first upon reduction with $\mathrm{D}$-glucose. Then, this $\mathrm{Cu}(\mathrm{I})$ reacts with 4-(prop-2-yn-1yloxy)benzaldehyde 2a to form the copper acetylide $[35,36] \mathbf{5}$, which reacts with azidobenzene 1a affording intermediate 6 by a $[3+2]$ cycloaddition reaction. The intermediate 6 yields 4-((1-phenyl-1H-1,2,3-triazol-4-yl)methoxy)benzaldehyde intermediate 7 after protonolysis of the $\mathrm{C}-\mathrm{Cu}$ bond. This inter- mediate reacts with 1,2-diaminobenzene (3a) under the formation of the corresponding Schiff' base, which further cyclizes to dihyrobenzimidazole. Finally, D-glucose [37] oxidizes the dihyrobenzimidazole to the benzimidazole. Moreover, if the reaction proceeds via route $B$ the benzimidazole formation from 4-(prop-2-yn-1-yloxy)benzaldehyde 2a and 1,2diaminobenzene 3a takes place first, followed by the formation of triazole by $\mathrm{CuAAC}$ reaction to give the desired product $\mathbf{4 a}$.

\section{Conclusion}

We developed a novel microwave-assisted, $\mathrm{Cu}(\mathrm{I})$-catalyzed, three-component reaction for the synthesis of 2-(4-((1-phenyl$1 H$-1,2,3-triazol-4-yl)methoxy)phenyl)-1 $H$-benzo[ $d]$ imidazoles in good to excellent yields. This protocol is applicable to various phenylazides, propargyloxybenzaldehydes and 1,2diaminobenzenes. 


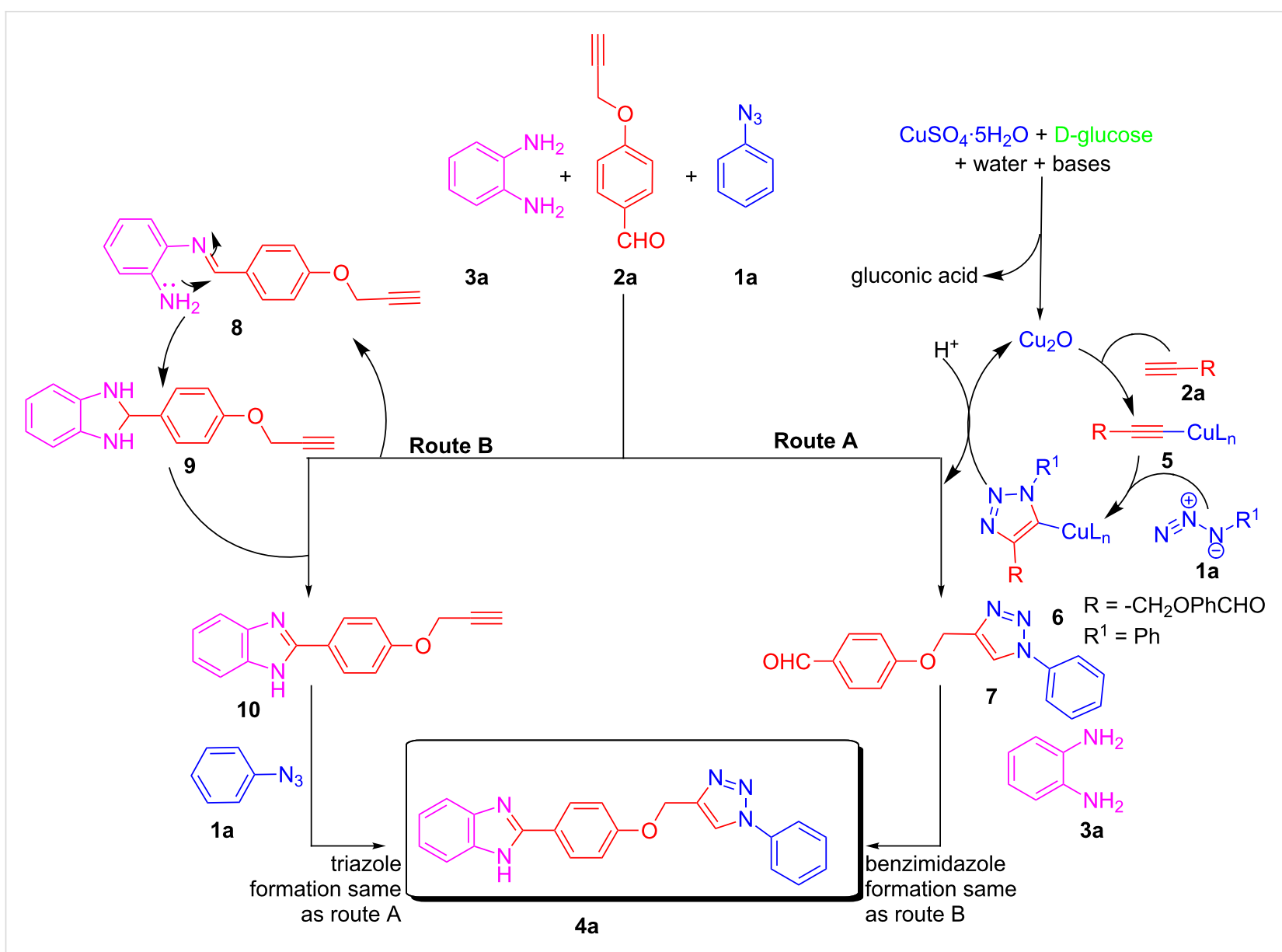

Scheme 2: Plausible mechanism for the synthesis of 2-(4-((1-phenyl-1H-1,2,3-triazol-4-yl)methoxy)phenyl)-1H-benzo[d]imidazole.

\section{Supporting Information}

\section{Supporting Information File 1}

Experimental procedures and analytical data. [http://www.beilstein-journals.org/bjoc/content/ supplementary/1860-5397-10-145-S1.pdf]

\section{Acknowledgements}

The authors acknowledge the financial assistance provided by a grant from the University of Delhi under the strengthening R\&D Doctoral Research Programme. Y.K. is thankful to the UGC (University Grant Commission) Delhi, India for providing a JRF (Junior Research Fellowship) and a SRF (Senior Research Fellowship).

\section{References}

1. Baviskar, A. T.; Madaan, C.; Preet, R.; Mohapatra, P.; Jain, V.; Agarwal, A.; Guchhait, S. K.; Kundu, C. N.; Banerjee, U. C.; Bharatam, P. V. J. Med. Chem. 2011, 54, 5013. doi:10.1021/jm200235u
2. Denny, W. A.; Rewcastle, G. W.; Bauley, B. C. J. Med. Chem. 1990, 33, 814. doi:10.1021/jm00164a054

3. Seyhan, E.; Sultan, N.; Nilgun, A.; Noyanalpan, N. Arzneim. Forsch. 1997, 47, 410.

4. Hu, L.; Kully, M. L.; Boykin, D. W.; Abood, N. Bioorg. Med. Chem. Lett. 2009, 19, 3374. doi:10.1016/j.bmcl.2009.05.061

5. Schiffmann, R.; Neugebauer, A.; Klein, C. D. J. Med. Chem. 2006, 49, 511. doi:10.1021/jm050476z

6. Verma, R. P. Bioorg. Med. Chem. 2005, 13, 1059 doi:10.1016/j.bmc.2004.11.033

7. Asensio, J. A.; Gomez-Romero, P. Fuel Cells 2005, 5, 336. doi:10.1002/fuce.200400081

8. Singh, N.; Jang, D. O. Org. Lett. 2007, 9, 1991. doi:10.1021/ol070592r

9. Chaudhuri, P.; Ganguly, B.; Bhattacharya, S. J. Org. Chem. 2007, 72, 1912. doi:10.1021/jo0619433

10. Pore, V. S.; Jagtap, M. A.; Agalave, S. G.; Pandey, A. K.; Siddiqi, M. I.; Kumar, V.; Shukla, P. K. Med. Chem. Commun. 2012, 3, 484. doi:10.1039/c2md00205a

11. Kamal, A.; Prabhakar, S.; Ramaiah, M. J.; Reddy, P. V.; Reddy, C. R.; Mallareddy, A.; Shankaraiah, N.; Reddy, T. L. N.;

Pushpavalli, S. N. C. V. L.; Pal-Bhadra, M. Eur. J. Med. Chem. 2011, 46, 3820. doi:10.1016/j.ejmech.2011.05.050 
12. Costa, M. S.; Boechat, N.; Rangel, E. A.; da Silva, F. C.; de Souza, A. M. T.; Rodrigues, C. R.; Castro, H. C.; Junior, I. N.; Lourenço, M. C. S.; Wardell, S. M. S. V.; Ferreira, V. F. Bioorg. Med. Chem. 2006, 14, 8644. doi:10.1016/j.bmc.2006.08.019

13. Holla, B. S.; Mahalinga, M.; Karthikeyan, M. S.; Poojary, B.; Akberali, P. M.; Kumari, N. S. Eur. J. Med. Chem. 2005, 40, 1173. doi:10.1016/j.ejmech.2005.02.013

14. Tietze, L. F.; Bell, H. P.; Chandrasekhar, S. Angew. Chem., Int. Ed. 2003, 42, 3996. doi:10.1002/anie.200200553

15. Saadeh, H. A.; Mosleh, I. M.; Mubarak, M. S. Molecules 2009, 14, 1483. doi:10.3390/molecules 14041483

16. Kouznetsov, V. V.; Gómez-Barrio, A. Eur. J. Med. Chem. 2009, 44, 3091. doi:10.1016/j.ejmech.2009.02.024

17. Lebens, M.; Shahabi, V.; Backstrom, M.; Houze, T.; Lindblad, M.; Holmgren, J. Infect. Immun. 1996, 64, 2144.

18. Baraldi, P. G.; Zaid, A. N.; Preti, D.; Fruttarolo, F.; Tabrizi, M. A.; laconinoto, A.; Pavani, M. G.; Carrion, M. D.; Cara, C. L.; Romagnoli, R. ARKIVOC 2006, No. vii, 20.

19. Gill, C.; Jadhav, G.; Shaikh, M.; Kale, R.; Ghawalkar, A.; Nagargoje, D.; Shiradkar, M. Bioorg. Med. Chem. Lett. 2008, 18, 6244. doi:10.1016/j.bmcl.2008.09.096

20. Wessjohann, L. A.; Rivera, D. G.; Vercillo, O. E. Chem. Rev. 2009, 109, 796. doi:10.1021/cr8003407

21. Shiri, M. Chem. Rev. 2012, 112, 3508. doi:10.1021/cr2003954

22. Brauch, S.; van Berkel, S. S.; Westermann, B. Chem. Soc. Rev. 2013, 42, 4948. doi:10.1039/c3cs35505e

23. Domling, A.; Wang, W.; Wang, K. Chem. Rev. 2012, 112, 3083. doi: $10.1021 / \operatorname{cr} 100233 r$

24. Ugi, I.; Meyr, R.; Fetzer, U.; Steinbruckner, C. Angew. Chem. 1959, 71, 386. doi:10.1002/ange.19590711110

25. Passerini, M. G. Gazz. Chim. Ital. 1921, 51, 126.

26. Van Leusen, D.; Van Leusen, A. M. Org. React. 2001, 57, 419 doi:10.1002/0471264180.or057.03

27. Strecker, A. Justus Liebigs Ann. Chem. 1854, 91, 349. doi:10.1002/jlac.18540910309

28. Hantzsch, A. Ber. Dtsch. Chem. Ges. 1881, 14, 1637. doi:10.1002/cber.18810140214

29. Biginelli, P. Ber. Dtsch. Chem. Ges. 1891, 24, 1317. doi:10.1002/cber.189102401228

30. Biginelli, P. Ber. Dtsch. Chem. Ges. 1891, 24, 2962. doi:10.1002/cber.189102402126

31. Kappe, O. C. Tetrahedron 1993, 49, 6937. doi:10.1016/S0040-4020(01)87971-0

32. Kumar, Y.; Bahadur, V.; Singh, A. K.; Parmar, V. S.; Singh, B. K. J. Indian Chem. Soc. 2013, 90, 1893.

33. García, M. A.; Ríos, Z. G.; González, J.; Pérez, V. M.; Lara, N.; Fuentes, A.; González, C.; Corona, D.; Cuevas-Yañez, E. Lett. Org. Chem. 2011, 8, 701. doi:10.2174/157017811799304232

34. Hein, E. J.; Fokin, V. V. Chem. Soc. Rev. 2010, 39, 1302. doi:10.1039/b904091a

35. Rostovstev, V. V.; Green, L. G.; Fokin, V. V.; Sharpless, K. B. Angew. Chem., Int. Ed. 2002, 41, 2596. doi:10.1002/1521-3773(20020715)41:14<2596::AID-ANIE2596>3.0.CO ;2-4

36. Tornøe, C. W.; Christensen, C.; Meldal, M. J. Org. Chem. 2002, 67, 3057. doi:10.1021/jo011148j

37. Rostamizadeh, S.; Aryan, R.; Ghaieni, H. R. Synth. Commun. 2011, 41, 1794. doi:10.1080/00397911.2010.492460

\section{License and Terms}

This is an Open Access article under the terms of the Creative Commons Attribution License

(http://creativecommons.org/licenses/by/2.0), which permits unrestricted use, distribution, and reproduction in any medium, provided the original work is properly cited.

The license is subject to the Beilstein Journal of Organic Chemistry terms and conditions:

(http://www.beilstein-journals.org/bjoc)

The definitive version of this article is the electronic one which can be found at:

doi:10.3762/bjoc. 10.145 